JOURNAL OF SECURITY AND SUSTAINABILITY ISSUES

ISSN 2029-7017 print/ISSN 2029-7025 online

2021 Volume 11

https://doi.org/10.47459/jssi.2021.11.11

\title{
SOCIAL SECURITY IN AGEING SOCIETIES IN A SUSTAINABLE DEVELOPMENT PERSPECTIVE. THE ANALYSIS OF CONTEXT INDICATOR OF WAYS OF ORGANIZING LIFE IN OLD AGE IN POLAND
}

\author{
Monika Adamczyk ${ }^{1}$, Alina Betlej ${ }^{2}$ \\ ${ }^{1,2}$ Institute of Sociological Sciences, The John Paul II Catholic University of Lublin, \\ Al. Ractawickie 14, 20-950 Lublin, Poland \\ E-mails: ${ }^{1}$ mdadamczyk@kul.pl; ${ }^{2}$ alina.betlej@kul.pl
}

Received 10 January 2021; accepted 4 April 2021; published 30 June 2021

\begin{abstract}
This paper examines the impact of a context indicator of integrated order, such as ways of organising one's life in old age, on social security issues. In the framework of ageing society it concerns the problems of socio-demographic determinants of life choices in old age, which are of the key importance for the sense of social security. Authors explore the results of the research on the representative sample of 1006 adult Poles, which has been carried out using the quantitative method - the diagnostic survey based on a questionnaire survey technique- in 2020. The preferred ways of organising one's life in old age were measured in five areas on the basis of the proprietary six-point nominal scale. The applied methodology helped to explore the preferences of the adult Poles regarding the forms of one's life organisation in old age and to study the determinants of the choices made. The analysis used contingency coefficients V- Cramer and Phi - to determine the strength of the relationship between the nominal variables assigned to the social security areas under study. The Chi-square test was used to determine the relationship between the studied areas of social security and age groups. The sociological approach in measuring the selected context indicator of integrated order in the sustainable development paradigm has been strongly emphasised by authors. The findings suggest that ways of organising one's life in old age are key factors for the sustainability of social security in ageing societies.
\end{abstract}

Keywords: social security, context indicator of integrated order, ways of organising one's life in old age, sustainability, ageing society

Reference to this paper should be made as follows: Adamczyk, M., Betlej, A. 2021. Social security in ageing societies in a sustainable development perspective. The analysis of context indicator of ways of organizing life in old age in Poland. Journal of Security and Sustainability Issues, 11, 147-157, https://doi.org/10.47459/jssi.2021.11.11

JEL Classifications: A14, B55

Additional disciplines: sociology

\section{Introduction}

Globally, the world's older population continues to grow at an unprecedented rate. Successfully dealing with the effects of the demographic transformations in today's ageing societies is more important than ever (Adamczyk, 2016; Adamczyk, Betlej, 2021). While the coronavirus pandemic has reshuffled life priorities, we should stress the importance of implementing strategies to fight the demographic and social crisis. Advocating for the sustainable transformation in the world is connected with introducing changes in defining the issues of social security (Angresano, 2007; Adamczyk et al., 2019; Lankauskienè, 2012). The results of the interaction between longer life expectancy and popularisation of new lifestyles are forcing a reorientation of understanding of security in ageing societies (Betlej et. al., 2021). The long term demographic transition inevitably leads to the crucial social and economic transformations (Adamczyk, 2016, pp. 5-13.). Public mechanisms do not seem to be prepared for the new economic and social burdens which pose a serious risk of destabilising the social 
order and the emergence of new social crises in the economic systems in European countries (Androniceanu et. al., 2020). The effects of ageing populations have been masked for many years by the short-term solutions (Arman et. al. 2021). The methodological reorientation shall allow us to see new areas of social security that may require intervention. The perspective of sociological research seems to provide interesting tools for both research and analysis, which application will enable a better understanding of importance of the context indicator of ways of organizing one's life in old age in the sustainable development paradigm.

Identifying problems faced by people living their own old age today requires us to abandon the stereotypical approaches in which senior citizens are portrayed as having a peripheral social position. Every person has the right to social security, understood as the possibility to benefit from social assistance. The development and establishment of the formal social security systems to provide income support and medical care has always been considered an important step in social advancemed (Aspalter, 2020). The emergence of the different formal and social protection mechanisms (compulsory contributory or non-contributory public social security schemes), were examples of institutional responses to the escalation of diverse social problems in the past.Understanding of ageing has been limited to a biological perspective for a long time. The process has been linked mainly to the progressive declines in social capacities as effects of irreversible transformations of human's body potentials. The results of the current study indicate a different relationship. Good levels of well- being and life satisfaction is also achieved by people categorized as being old. The more global perspective to understand this complex issue is evident. Retirement poses various problems for people in different age categories (Avers, 2020). One should be associated with the increasing risk of physical and cognitive impairments. Dependence on others and threat of death are also related to this field of analysis. Challenges to the well-being of the population should be considered as factors of sustainable development (Betlej, 2017).

In the paper we discuss the issue of distribution of public resources. We redefine old age in its social dimension and identify coping strategies for potential problems occurring in this phase of life. (Avers, 2020; Aspalter, 2020; Ribeiro et al.,2017). Consequently, problems of ageing society became the crucial subject of sociological and economic analysis. The theoretic frames of ageing studies are multidimensional. The category of social security is a very important issue in this context, requiring the implementation of an integrated strategy to address such problems at national and local level, involving the individual in a process of planning for the future. Efficient capacities of learning how to plan and manage the ageing process is considered as the part of the social sustainability strategy (Betlej et. al., 2017; Adamczyk, 2016; Fedulova et al., 2019)). To deal with these challenges, this study aims at offering an overview of the chosen theories in the field of social security and concerns the issue of socio-demographic factors of the choices of life forms in old age.

The first part of the paper presents theories linked to social security and its associations to the sustainable development during ageing. It starts from an individual perspective to reach a more social level, by detailing the strategy selection. The second part gives an overview of the authors' findings in Poland. Preferred forms of organisation of one's life in old age will be measured in five areas based on the proprietary six-level nominal scale. The aim of the research it to analyse the background conditions of adult Poles' preferences for organizing life in old age, as well as to discover the determinants of their choices. This perspective shall include the scope of sustainable development principles as the context indicator for measuring integrated order. The application of this category will contribute to the refinement of the considered paradigm, as well as to rethinking the position of people excluded from mainstream social activity due to their age and inability to organise forms of social life effectively. This context indicator is being introduced as crucial for reaching ageing sustainability. We answer questions: first - what is the funtion of social security in sustainable development of ageing societies? Secondly - what is the funtion of the context indicator of forms of organizing one's life in old age in refinement of the integrated order perspective? Discussion comes up to concrete conclusions to support the role of conscious choices of life strategies in old age. 


\section{Social security objectives in the integrated order perspective- theoretic approach}

When translating the assumptions of sustainable development into social security, it is seen the necessity of starting with a precise definition of social security, whose structural elements are the institutions ensuring security and the legal system, and whose functional binders are social threats triggering the system (old age, illness, disability, poverty, etc.). Ensuring security is one of the most important spheres of state activity and one of the basic guarantors of maintaining the socio-economic order (Carmel et. al., 2021). The definition of social security can be found, among others, in the documents of the International Labour Organisation, which emphasises the prevention of the economic and social misery. According to the ILO, social security is the protection that society provides to individuals and households for ensuring access to health care and guaranteeing income security, especially while ageing, unemployment, illness, disability, occupational accident, maternity, occupational accident, etc. (ILO 2016:2). The analysis of social security can be conducted on a macro- or micro-social perspective. The second approach refers to the notion of unmet needs. This view is based on the assumption that unmet needs result in a state of lack/threat, which can become a factor for the accumulation of various difficult situations in the lives of individuals and their families (Gerber, J.P., et al., 2016; Fitzgerald et al., 2014). Threats to the implementation of individual needs in the area of social security are directly related to the failure to satisfy basic human needs (Hollanders, 2010). From the perspective of sustainable social development and the corresponding social order, the failure to meet individual needs and thus undermine the sense of security of the individual, if it results from systemic flaws such as lack of health infrastructure, inequalities in access to goods and information, intentional omission or exclusion from financial transfers, can lead to social destabilization (Bogoviz et al., 2020). Therefore, according to The ILO Social Protection Floors Recommendation, 2012 (ILO, 2012) social security understood as the right to social security is a human right and all people should be guaranteed at least a minimum level of basic social protection. Ensuring social security is a social and economic necessity to combat poverty and social exclusion (ILO, 2008). To guarantee a minimum level of social security, the level of social protection should consist of at least four basic social security guarantees: basic health care; basic income security in childhood, adulthood and old age for all residents and all children (ILO, 2012). Sustainable social security in old age should therefore be one of the priority actions both socially and individually.

It shall be a cornerstone of public programmes in many European countries, which cover the whole range of variables considered important for social inclusion at a general level. (Semenova et al., 2020). Social security is an interdisciplinary category. The theoretic approaches are divided into three groups: political, efficiency and narrative ones. The political theories take into consideration models of power relations for what are defined to be the social resources of older people in the market (Jing et al., 2014). The efficiency approach discuss the function of social security in building the welfare for the elderly based on increasing their social capital management productivity. Considerations may also include the theories of chain letter and capitalism (Weaver, 1986). The theory of ageing society emphasises the aspect of social and environmental conditions in relation to the whole system of social organisation. A stable development of social systems is possible only in a situation of maintaining relative balance at the level of different social forces. The analysis of this concept directs our attention to questions of universal accessibility, the normative level of social protection for older people and its individual, social and axiological conditions (Weaver, 1986). The term 'social' refers to the basic subsistence needs of each individual. We can also consider this concept in a broader perspective as the comprehensive physical and spiritual growth of the human being.

Irrespectively of the cited definitions, the main objectives of social security are considered to be:

- reducing income instability, including the eradication of poverty, and improving access to health services for all people, in order to ensure their ability to work and live with dignity;

- reducing inequality and injustice;

- providing adequate benefits as a legally guaranteed entitlement. (ILO, 2011)

We define social security as the state of being free from threats which result in a lack or insufficiency of means of subsistence. In this context, a lack of means of subsistence is understood as both an insufficient level of monetary or material resources available to an individual or family and a lack of appropriate care when the state 
of health or the situation in which a person finds themselves requires that they be provided with such a form of assistance (Kröger, 2011; Le Bihan et al., 2006; Lee, 2020). These risks are mainly social such as: sickness, accidents at work, disability or old age which is interesting from our point of view. A study of social security in ageing societies should definitely consider a social context of transformations (Mahjoub et. al., 2020). Understanding the importance of the defined phenomenon in sustainable development perspective requires the introduction of the category of integrated order into the analysis. It is explained as an expected destination's state of developmental changes that links all the component orders in the adopted paradigm. In other words, integrated order is the target layout of sustainable development (Menshikov et al., 2020; Ohotina et al., 2018a, 2018b). It can also be considered as a model for developmental changes displaying sustainability properties (Raudeliūnien et al., 2020).

The overriding aim of shaping integrated order is to balance and harmonise the structural transformations that may lead to a gradual reduction of the existing social inequalities. The effect of these actions should be the structuration of systems enabling the minimisation of diverse social, ecological and functional conflicts. The emergence of such systems will primarily help to improve the quality of social life and economic efficiency based on the ethical approach. Integrated order is also synonymous with the coherent development of social, economic and environmental order. The integrity of orders is the result of balanced protection of natural, social (areas: individual and society) and anthropogenic (areas: culture and economy) capital (Stattin et al., 2021). In sociological sciences, we primarily consider the problems of integrated order through the lens of quality of life assessment (Adamczyk et al., 2021). In other words, integrated order means an integrated quality of life, i.e. a combination of physical order with mental and emotional (spiritual) order.

Quality of life is a very important element of the ongoing discussions about economic prosperity and sustainable development. This category is often subsumed under the term "economic growth" (Čižo et. al, 2020). The assumption that more income and consumption equals better welfare is made very often. In sociological sciences, the exclusive identification of consumption with well-being is questioned. Through the integrative approach to quality of life measurements we analyse a much broader research context than the economic one. The findings suggest that the approach can be applied to analyses of social security in ageing societies. It combines measures of human needs with a subjective view on happiness and an individual well-being. Therefore, equating social security solely with economic indicators was questioned in our research. The research methodology provided insights into the potential of sociological approaches in explaining the complexity of social security in the sustainability of ageing societies.

\section{Research Method}

The demographic ageing of the population of Europe and some highly developed countries is a global process (Betlej, Leśniak-Moczuk, 2017). The aim of the research was to identify problem areas for the sense of social security in old age, as the contextual indicator of the level of sustainable development within the social order. For the purpose, we surveyed 1006 adult Poles. In the research we used a quantitative method - a diagnostic survey carried out on the basis of the proprietary survey questionnaire in 2020. In the following analysis we try to identify problems for the old age phase of life. For this purpose, we asked respondents what they fear in old age. In our view, addressing health issues and meeting needs for independence, activity, is important from both an individual and social perspective. The satisfaction of supra-subjective needs necessitates the introduction of another person (caregiver) into one's own life space; moreover, it is this other person - caregiver, counsellor - who becomes the condition for maintaining one's own existence at the right level. The quality of life of a person with supra-subjective needs therefore depends on the quality of the relationship which will link the two subjects of the same helping relationship, the elderly person in care and the caregiver. Regardless of whether this relationship takes place within the family environment or appropriate and specific institutions. Adopting such a perspective fits into the area of social order research. It is both one of the priority areas for sustainable development and a context indicator for measuring the area of social inclusion.

The study involved 1006 adult Poles aged 15 and over. In order to distinguish groups of respondents according 
to the life phase they are in, we recoded the variables and created the age groups corresponding in some respects to the life phases proposed by Daniel J. Levinson (D.J. Levinson, 1959, 1977,1978). The adoption of this division allowed the creation of four such groups:

1. People aged $15-20$ years accounted for $7.1 \%$ of all study subjects.

2. People aged $21-40$ years accounted for $33.4 \%$ of all study subjects.

3. People aged $41-59$ years accounted for $30.2 \%$ of all study subjects.

4. People aged 60 and over accounted for $29.3 \%$ of all study subjects.

The gender distribution of the study population was as follows:

$-48.2 \%$ (485) of the survey respondents were male,

$-51.8 \%(521))$ of the survey respondents were female.

In order to identify problem areas for the sense of social security in old age, in the proposed sense of freedom from threats resulting in a lack of or inadequate means of subsistence for the individual or family, we proposed the proprietary indicators of the threat to social security. We considered the following as threats:

- poor living conditions,

- difficulties to maintain;

- disease infirmity and dependence on others;

- being a burden to others;

- loneliness;

- one's own death;

- death of loved ones and acquaintances;

- excess of time with which one does not know what to do;

- no particular concerns due to old age.

The selection of the indicators was based on research by Robyn Joy Brunton and Greg Quartly-Scott (Brunton et al., 2015), among others. In order to identify the best, according to the respondents, strategies for organising one's life in old age, a proprietary tool was used in the form of a scale consisting of five statements. The respondents were asked to respond to them on a scale of 1 to 6 . The scale consisted of statements that dealt with ways of organising one's life in old age and the extent to which they meet the needs of older people:

1. Living in one's own flat and using temporary help from people close to oneself - family, friends, neighbours.

2. Living in one's own flat, with the help of third persons, e.g. a carer for the elderly.

3. Sharing the home with children, grandchildren or extended family.

4. Living together with other older people, e.g. in a nursing home, a rest home.

5. Living in one's own home with the support of day care centres.

\section{Results}

In order to identify problem areas in terms of the proposed understanding of the sense of social security felt in old age, we asked respondents what they feared most when thinking about their old age, regardless of their age and living situation as seen at the figure 1 . 


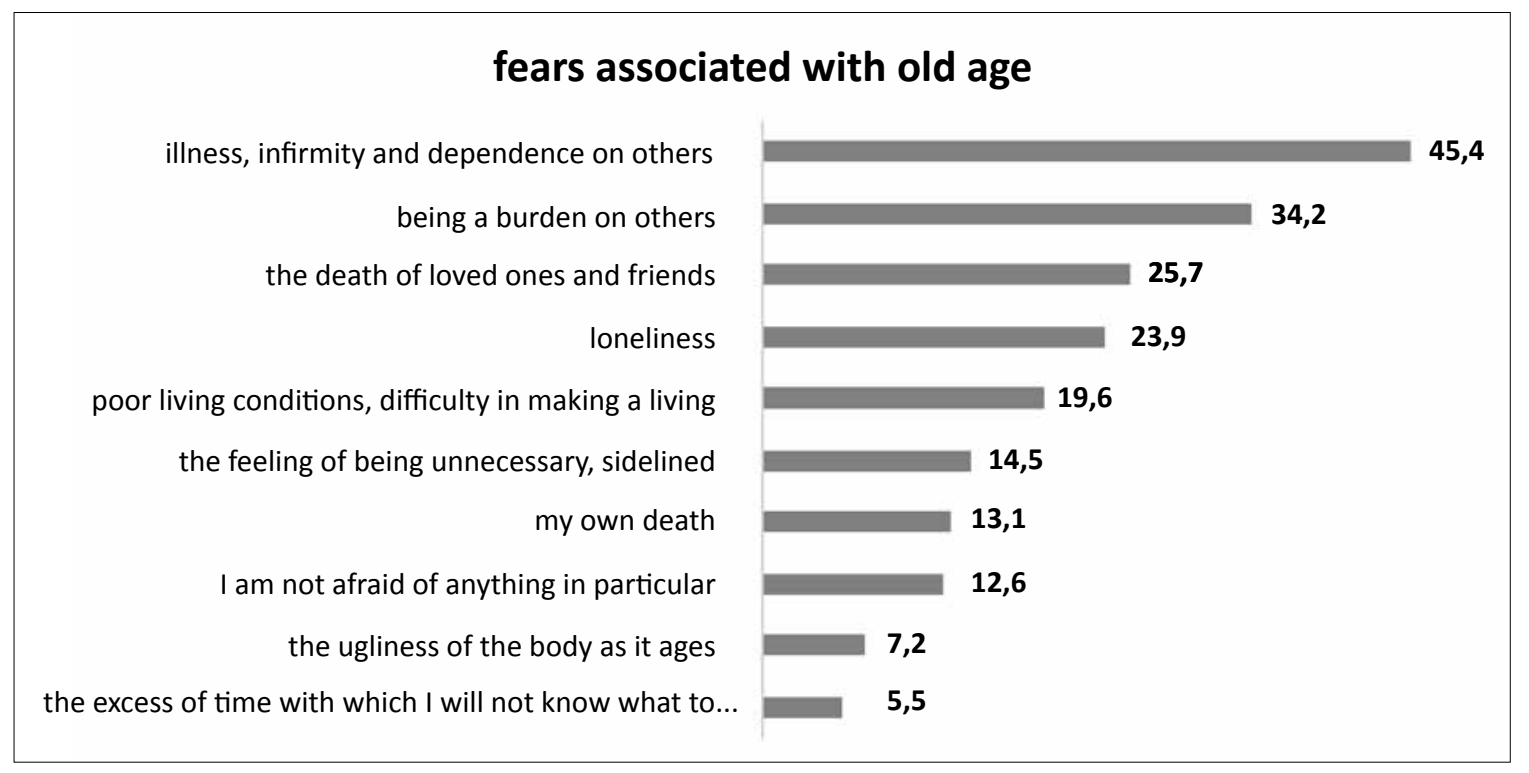

Fig. 1. Fears about old age in $\%$

Source: study based on own research

According to the survey, the greatest concerns irrespective of age are illness, infirmity and dependence on others, a problem area for $45.5 \%$ of all respondents. Adopting the definition of social security as freedom from threats that cause lack or deprivation of livelihoods for an individual or family, the proposed indicators clearly show that health concerns are felt. In the context of sustainable development and demographic changes, such as increasing healthy life expectancy, the need to develop adequate infrastructure becomes obvious. Its aim should not only be to provide opportunities for adequate disease prevention. An important aspect of institutionbuilding should be to ensure that people can organise their lives appropriately in old age. This should prevent the risk of social exclusion or poverty in this phase of life. Nearly $20 \%$ of all respondents fear poor living conditions and difficulties in making a living.

Our research confirms that as people move into older age groups, fear of illness, infirmity and dependence on others will increase. For 52, 5\% of all our respondents in the $60+$ age group, this is the area that causes the most problems. In the youngest age group of 15-20 years this problem affects $35.2 \%$ of people. Our analysis shows that all the indicators in the group on independence, living conditions and health are linked to age. The older people get, the more important these areas of life become for them. This is illustrated by the distribution of data in the figure below. 


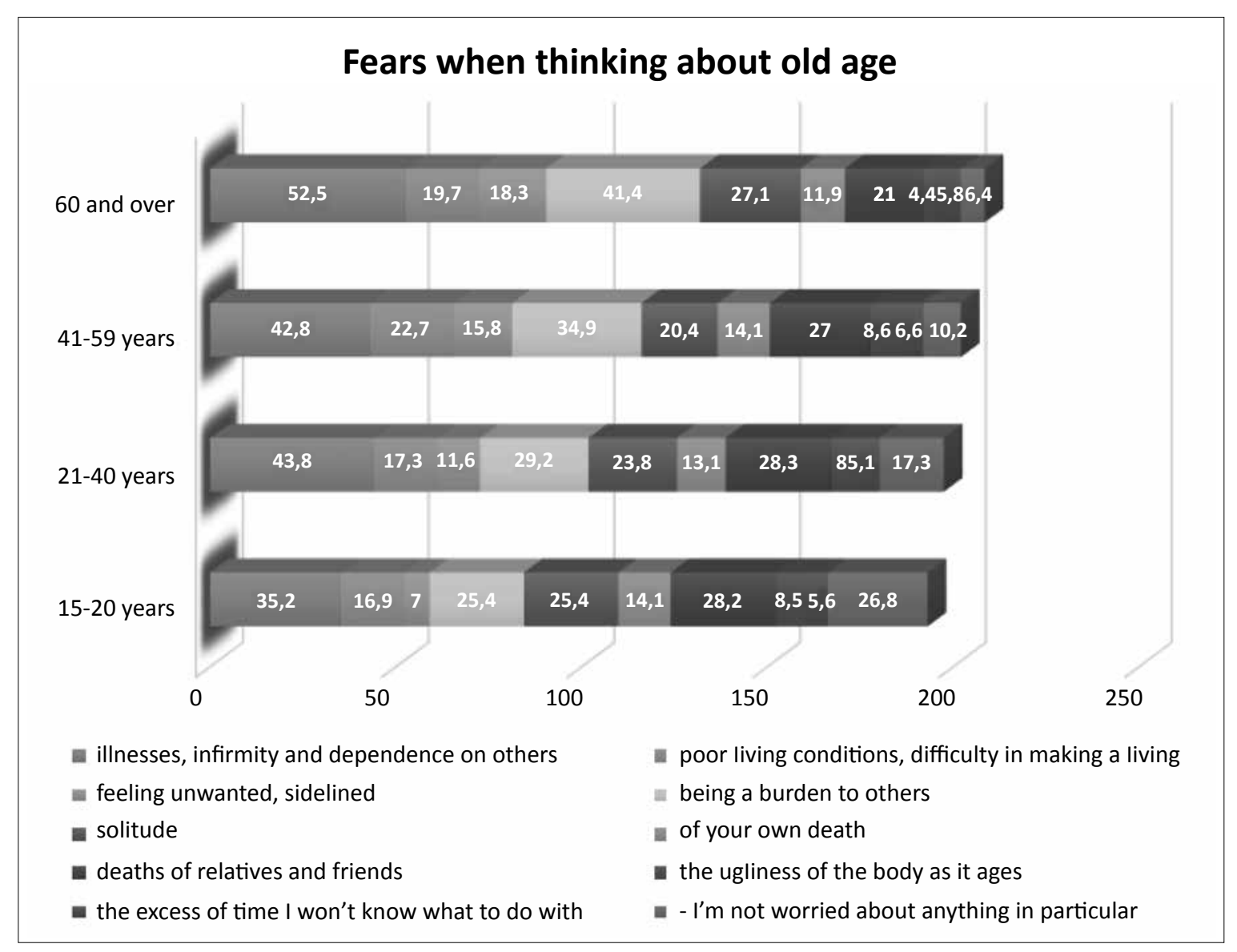

Fig. 2. Regardless of your age and living situation, please tell me what you fear most when thinking about your old age - in \%

Source: study based on own research

In the analysis of the research results, the contingency coefficients - V-Cramer and Phi - were used to determine the strength of the relationship between the nominal variables assigned to the 10 social security areas studied. Using the Chi-square test, we determined the existence of relationships between the social security areas studied and age groups. A very important from the point of view of preparing institutional infrastructure in the area of broadly understood health protection and social care is the issue of defining which areas of social protection should be the focus of attention. This leads to the question of which areas are relevant to particular age groups? Should different approaches to this question be considered and can statistical correlations be found?

The areas of social security related to health and independence were found to be statistically significant. The probability of indicating illness, infirmity and dependence on others increases significantly from the age group of 21-40 years to the oldest as described the table $1 .$. The above variation is statistically significant, which is confirmed by the result of Chi2 Persona independence test $(\mathrm{N}=1006)=10.265 ; \mathrm{p} \leq 0.05$. The correlation between health area and age group should be assessed as weak (Cramer's $\mathrm{V}=0.016 ; \mathrm{p} \leq 0.05$ ).

Tab.1. Regardless of how old you are and what your living situation is, please tell me what you fear most when thinking about your old age - illness, infirmity and dependence on others - in \% 


\begin{tabular}{|c|c|c|}
\hline \multicolumn{3}{|c|}{$\begin{array}{c}\text { Regardless of how old you are and what your living situation is, please tell me what you } \\
\text { fear most when thinking about your old age - illness, infirmity and dependence on others - in \% }\end{array}$} \\
\hline & Not mentioned & mentioned \\
\hline $15-20$ years & $8.4 \%$ & $5.5 \%$ \\
\hline $21-40$ years & $34.4 \%$ & $32.2 \%$ \\
\hline $41-59$ years & $31.7 \%$ & $28.4 \%$ \\
\hline 60 and over & $25.5 \%$ & $33.9 \%$ \\
\hline Total $N=1006$ & $100.0 \%$ & $100.0 \%$ \\
\hline
\end{tabular}

Source: study based on own research

The likelihood of feeling useless, sidelined also increases with age (see the table 2). This relationship is statistically significant, as confirmed by the result of the Chi2 Persona independence test $(\mathrm{N}=1006)=9.299 ; \mathrm{p} \leq 0.05$. The correlation between this area and the age group should be assessed as weak (Cramer's $V=0.026 ; \mathrm{p} \leq 0.05$ ).

Tab.2. Regardless of how old you are and what your life situation is, please tell me what you fear most when thinking about your old age - feeling useless, being sidelined - in \%

\begin{tabular}{|c|c|c|}
\hline \multicolumn{3}{|c|}{$\begin{array}{c}\text { Regardless of how old you are and what your life situation is, please tell me what you } \\
\text { fear most when thinking about your old age - feeling useless, being sidelined - in \% }\end{array}$} \\
\hline & Not-mentioned & mentioned \\
\hline $15-20$ years & $7.7 \%$ & $3.4 \%$ \\
\hline $21-40$ years & $34.5 \%$ & $26.7 \%$ \\
\hline $41-59$ years & $29.8 \%$ & $32.9 \%$ \\
\hline 60 and over & $28.0 \%$ & $37.0 \%$ \\
\hline Total $N=1006$ & $100.0 \%$ & $100.0 \%$ \\
\hline
\end{tabular}

Source: study based on own survey

It appears that there is a relationship between age and fear of being a burden to others (see the table 3 ). This relationship is statistically significant, as confirmed by the result of the Chi2 Persona independence test $(\mathrm{N}=1006)=13.027 ; \mathrm{p} \leq 0.05$. The correlation between this area and age group should be assessed as weak (Cramer's $\mathrm{V}=0.05 ; \mathrm{p} \leq 0.05)$.

Tab.3. Regardless of how old you are and what your living situation is, please tell me what you fear most when thinking about your old age - being a burden on others - in \%

\begin{tabular}{|c|c|c|}
\hline \multicolumn{2}{|c|}{$\begin{array}{c}\text { Regardless of how old you are and what your living situation is, please tell me what you } \\
\text { fear most when thinking about your old age - being a burden on others - in \% }\end{array}$} \\
\hline & Not-mentioned & mentioned \\
\hline $15-20$ years & $8.0 \%$ & $5.2 \%$ \\
\hline $21-40$ years & $36.0 \%$ & $28.5 \%$ \\
\hline $41-59$ years & $29.9 \%$ & $30.8 \%$ \\
\hline 60 and over & $26.1 \%$ & $35.5 \%$ \\
\hline Total $\mathrm{N}=1006$ & $100.0 \%$ & $100.0 \%$ \\
\hline
\end{tabular}

Source: study based on own survey

In conclusion, it should be stated that the variable age differentiates statistically significantly the area of fears related to old age. The older people get, the more importance they attach to their own health and the more they fear illness, infirmity and dependence. They also fear the feeling of being a burden to others or the feeling of being sidelined and useless. From the perspective of indicators of social inclusion and risk of social exclusion, the factors adopted are interesting and important contextual indicators of social inclusion. They indicate a 
clearly increasing level of fear among Poles about the potential inability to function independently in the latter phase of life while ageing. This is all the more important in light of the challenges arising from the latest Central Statistical Office report "Life Expectancy in 2019" (CSO 2019), which estimates life expectancy in Poland for men at 74.1 years and for women at 81.8 years. Compared to 2018, life expectancy has increased by 0.3 and 0.1 years respectively, while taking 1990 into account - by 7.9 and 6.6 years. Poles are living longer, aware that they will also experience old age with all the aspects characteristic of this phase of life. The provision of health and social care infrastructures, as well as services related to social activities in the broadest sense, can be crucial for building an integrated society.

\section{Discussion and Conclusions}

The analyses show that the areas of social security that adult Poles are particularly concerned about are health and social ties in a broad sense. Relating these fears to the scheme of mutual relations between needs and areas of social security proposed earlier, it is clearly visible that the respondents are not afraid of basic needs connected with maintaining physiological safety (Brunton et. al. 2015). In old age, Poles fear, above all, illness, infirmity and dependence on others, which is associated with needs in the area of security (care, support, peace, freedom from fear) - understood as the absence of a threat to the realisation of the needs of dependent and nondependent persons, including children, people with disabilities, the elderly.

The equally important areas of social security are the related higher needs, i.e. love and belonging (bonding, affirmation, being loved), the need for respect and recognition as well as self-realization. It appears that in Polish society, almost 30 years after the introduction of the market economy system, material needs are no longer important (Adamczyk et al., 2021). In the case of one's life planning in old age, it is important to be free from the threat of loneliness, lack of loved ones, lack of relationships with others, lack of support in the family and local environment in case of difficult situations (Popkova, 2020). The threat of a broadly understood sense of being a burden, or the lack of opportunities for self-realisation understood as a sense of being sidelined and useless, are the key risk areas.

The empirical analyses showed that there is a positive relationship between age and areas of concern related to old age. This means that a change in the value of the age variable (moving to older age groups) causes an increase in old age functioning anxiety (Carmel et al., 2021). This positive relationship between age and areas of concern is grounded in the professional literature. The theories indicate that there is a kind of consensus on the view that with age, the level of concern about health, independence, self-reliance, etc. increases. (Adamczyk, 2019). In empirical research, however, these concerns have not been linked to social security issues often enough. It seems that this issue still requires in-depth research, so our results provide statistically confirmed evidence that population ageing and social security (selected indicators) should be discussed in the perspective of sustainable development.

\section{References}

Adamczyk, M.; Betlej, A. 2021. Social determinants of digital exclusion in an ageing society. The case of Poland, Entrepreneurship and Sustainability Issues, 8 (3), 122-135. http://doi.org/10.9770/jesi.2021.8.3(7)

Adamczyk, M.; Betlej, A.; Gondek, J.; Ohotina, A. 2019. Technology and sustainable development: towards the future?, Entrepreneurship and Sustainability Issues, 6(4), 2003-2016. https://doi.org/10.9770/jesi.2019.6.4(32)

Adamczyk, M. 2016. Education in late adulthood as a form of social participation of older people, in: Mensikovs V. (ed. by) Proceedings of the International Scientific Conferences of Faculty of Social Sciences of Daugavpils University. The materials of the International Scientific Conference, Daugavpils: 5-13.

Androniceanu, A., M.; Georgescu, I.; Tvaronavičienė, M.; Androniceanu 2020. A. Canonical Correlation Analysis and a New Composite Index on Digitalization and Labor Force in the Context of the Industrial Revolution 4.0., Sustainability, 12 (6812). 
Arman, R., Kadefors, R., \& Wikström, E. 2021. 'We don't talk about age': A study of human resources retirement narratives. Ageing and Society, 1-27. https://doi.org/10.1017/S0144686X21000246

Aspalter, Ch. 2020. Healthy Aging, Encyclopedia of Gerontology and Population Aging, 1-14. https://doi.org/10.1007/978-3-31969892-2

Avers, D. 2020. Aging Demographics and Trends, Guccione's Geriatric Physical Therapy, 17-37. https://doi.org/10.1016/B978-0-32360912-8.00002-6

Betlej, A. 2017. Peril and Promise of Internet Technology for Future Social Order. In: Zacher, L. W. (ed. by). Technology, Society and Sustainability. Selected Concepts, Issues and Cases. Springer: 117-128.

Betlej, A.; Leśniak-Moczuk, K. 2017. Technology and an aging population in Network Society. Towards Virtually-based Communities. Roczniki Nauk Społecznych= Annals of Social Sciences, 9(45), Issue 2: 61-72.

Betlej, A.; Kačerauskas, T. 2021. Creative Urban Sustainability: the case of Lublin. Sustainability, 13 (7), 4072, 1-15. https://doi. org/10.3390/su13074072

Bogoviz, A.V.; Lobova, S.V.; Alekseev, A.N. 2020, Social development versus economic growth: current contradictions and perspectives of convergence, International Journal of Sociology and Social Policy, Vol. 41 No. 1/2, 3-14. https://doi.org/10.1108/IJSSP-03-2020-0061

Brunton, R. J.; Quartly-Scott, G. 2015. Do We Fear Ageing? A Multidimensional Approach to Ageing Anxiety, Educational Gerontology 41(11):150527100153004, https://doi.org/10.1080/03601277.2015.1050870

Carmel, S.; Tur-Sinai, A. 2021. Cognitive decline among European retirees: Impact of early retirement, nation-related and personal characteristics. Ageing and Society, 1-27. https://doi.org/10.1017/S0144686X21000064

Čižo, E.; Lavrinenko, O.; Ignatjeva, S.; Danileviča, A.; Tvaronavičienè, M. 2020. Financial development and its impact on economic growth (the case of Latvia), Journal of Security and Sustainability Issues, Vol. 10, No. 2, 465-476.

Fedulova, I., Ivanova, V., Atyukova, O. \& Nosov, V. 2019. Inclusive Education as a Basis for Sustainable Development of Society. Journal of Social Studies Education Research, 10(3), 118-135.

Fitzgerald, K. G.; Caro, F. G. 2014. An overview of age-friendly cities and communities around the world. Journal of Aging \& Social Policy, 26(1-2), 1-18.

Hollanders, D. 2010. The political future of social security in ageing societies. Acta Politica, 45, 386-388. https://doi.org/10.1057/ ap. 2010.13

International Labour Office 2016. Europe. 2016 The Right to Social Security in the Constitutions of the World: Broadening the moral and legal space for social justice, Vol. 2. https:/www.ilo.org/wcmsp5/groups/public/---ed_norm/--normes/documents/publication/ wcms_518153.pdf

International Labour Office 2012. Social security for all Building social protection floors and comprehensive social security systems, vol.4 https://www.social-protection.org/gimi/RessourcePDF.action?id=34188

International Labour Office 2011. The strategy of the International Labour Organization Social security for all Building social protection floors and comprehensive social security systems.

International Labour Office 2008. Social Security for all. Investing in social justice and economic development. Social Security Policy Briefings, Paper 7 https://www.ilo.org/wcmsp5/groups/public/---ed_protect/---soc_sec/documents/publication/wcms_secsoc_10177.pdf

Jing, Y.; Besharov, D. J. 2014. Collaboration among government, market, and society: Forging partnerships and encouraging competition. Journal of Policy Analysis and Management, 33(3), 835-842.

Kröger, T. 2011. Retuning the Nordic welfare municipality: Central regulation of social care under change in Finland. International Journal of Sociology and Social Policy, 31(3/4), 148-159.

Lankauskienè, T.; Tvaronavičienė, M. 2012. Security and sustainable development: approaches and dimensions in the globalization context. Journal of security and sustainability issues, 1 (4), 287-297

Le Bihan, B.; Martin, C. 2006. A comparative case study of care systems for frail elderly people: Germany, Spain, France, Italy, United Kingdom and Sweden. Social Policy and Administration, 40(1), 26-46.

Lee, K. 2020. Social Security. Ploughshares 46(4), 110. doi:10.1353/plo.2020.0161. 
Levinson, D.J. 1978. The seasons of a man's life, Knopf, New York.

Levinson, D. J. 1959. Role, personality, and social structure in the organizational setting. The Journal of Abnormal and Social Psychology, 58, 170-180.

Levinson, D. J. 1977. The mid-life transition: A period in adult psychosocial development. Journal for the Study of Interpersonal Processes, 40, 99-112.

Mahjoub B., L.; Amara, I. 2020, The impact of cultural factors on shareholder governance and environmental sustainability: an international context, World Journal of Science, Technology and Sustainable Development, 17(4), 367-385. https://doi.org/10.1108/WJSTSD-06-2020-0060

Menshikov, V.; Kokina, I.; Komarova, V.; Ruza, O.; Danilevica, A. 2020. Measuring multidimensional poverty within the resource-based approach: a case study of Latgale region, Latvia, Entrepreneurship and Sustainability Issues 8(2), 1211-1227. https://doi.org/10.9770/ jesi.2020.8.2(72)

Ohotina, A.; Lavrinenko, O.; Gladevich, J.; Lazdans, D. 2018a. The investment climate in Latvia's, Lithuania's and Belarus's cross border regions: the subjective-objective assessment, Entrepreneurship and Sustainability Issues 6(2), 767-780. https://doi.org/10.9770/ jesi.2018.6.2(20)

Ohotina, A.; Lavrinenko, O.; Ignatjeva, S.; Lonska, J. 2018b. Socio-economic security as a determinant of regional differences in the investment climate in the region, Journal of Security and Sustainability Issues, 7(3), 427-438. https://doi.org/10.9770/jssi.2018.7.3(5)

Popkova, E. 2020, "The social management of human capital: basic principles and methodological approaches", International Journal of Sociology and Social Policy, 41 No. 1/2, 24-36. https://doi.org/10.1108/IJSSP-03-2020-0062

Raudeliūnienė, J.; Tvaronavičienė, M.; Blažytė, M. 2020. Knowledge Management Practice in General Education Schools as a Tool for Sustainable Development. Sustainability, 12, 4034. https://doi.org/10.3390/su12104034

Ribeiro,M; da Silva Borges,M.; Cavalcanti Ferreira de Araujo, T., C.; dos Santos Souza,M., C. 2017. Coping strategies used by the elderly regarding aging and death: an integrative review. Revista Brasileira de Geriatria e Gerontologia 20(6). https://doi.org/10.1590/198122562017020.170083

Semenova, G.N.; Larionova, E.I.; Karpovich, O.G.; Shkodinsky; S.V.; Ouroumova, F.M. 2020. Social integration as a factor of economic growth: experience and perspectives of developing countries. International Journal of Sociology and Social Policy, $41(1 / 2), 37-49$. https://doi.org/10.1108/IJSSP-03-2020-0083

Stattin, M.; Bengs, C. 2021. Leaving early or staying on? Retirement preferences and motives among older health-care professionals. Ageing and Society, 1-27. https://doi.org/10.1017/S0144686X2100026X

Weaver, C. 1986. Social Security in Aging Societies. Population and Development Review, 12, 273-294. https://doi.org/10.2307/2807911

Monika ADAMCZYK is an associate professor of Social Sciences in the Field of Sociology. An employee of the Institute of Sociological Sciences of the John Paul II Catholic University of Lublin (Poland). Author of Books: Social Determination of Successful Ageing and Active Preparation for Retirement (2019), Discovering the Dynamic Third Age (edit.) (2016), Oldness Between Tradition and Modernity (edit.) (2016), Actively Towards Retirement (2015), Introduction to Social Capital Theory (2013) and many articles and expert opinions.

ORCID ID: https://orcid.org/0000-0002-1331-6026

Alina BETLEJ is an assistant professor, PhD in the field of sociology. An employee of the Institute of Sociological Sciences of the John Paul II Catholic University of Lublin (Poland). She is interested in Internet sociology, digital sociology, economic sociology, sustainable development, forecasting. She is an author of a book: Network society-potentials of change and ambivalence eefects (2019. She is an expert in technology assessment.

ORCID ID: https://orcid.org/0000-0002-2729-6564

This work is licensed under the Creative Commons Attribution International License (CC BY). http://creativecommons.org/licenses/by/4.0/ 